\title{
VARIATION OF CLIMATIC AND PHYSICAL CO-DETERMINANTS OF PHYTOPLANKTON COMMUNITY IN FOUR NICTEMERAL SAMPLING DAYS IN A SHALLOW TROPICAL RESERVOIR, SOUTHEASTERN BRAZIL
}

\author{
RAMÍREZ, J. J. ${ }^{1}$ and BICUDO, C. E. M. ${ }^{2}$ \\ ${ }^{1}$ Departamento de Biología, Universidad de Antioquia, Apartado aéreo 1226, Medellín, Colombia \\ ${ }^{2}$ Seção de Ficologia, Instituto de Botânica, C.P. 4005, CEP 01061-970, São Paulo, SP, Brazil \\ Correspondence to: Carlos Eduardo M. Bicudo, Seção de Ficologia, Instituto de Botânica, C.P. 4005, \\ CEP 01061-970, São Paulo, SP, Brazil, e-mail: cbicudo@terra.com.br \\ Received August 26, 1999 - Accepted August 28, 2000 - Distributed February 28, 2002
}

(With 8 figures)

\begin{abstract}
Spatial and temporal variation of climatic and physical characteristics in a shallow tropical reservoir in the city of São Paulo, Southeastern Brazil, and their possible influence on the dynamics of the phytoplankton population. Samples were taken at 5 depths of the water column (subsurface: $1 \% \mathrm{I}$, $10 \% \mathrm{I}_{\mathrm{o}}, 2 \mathrm{~m}$, and bottom) and at 4 hour intervals (6:00, 10:00, 14:00, 18:00, 22:00, 2:00, and 6:00 h) during summer (March 3-4), fall (June 13-14), winter (August 29-30), and spring (November 2930 ) of 1994 at a single sampling station. Garças Reservoir (23⒊' S, $46^{\circ} 37^{\prime} \mathrm{W}$ ) is a kinetic turbulent system, highly influenced by winds, with stratification that may last for days or weeks, and which undergoes mixing periods more than once in a year. A thermal pattern of this type is comparable to the warm discontinuous polymictic. Considering its optical properties, the water body was classified as an ecosystem with moderate turbidity, which decreases basically due to increased phaeopigment concentration during the spring. Also, the reservoir is an ecosystem whose phytoplanktonic community is subjected to stress, the degree of which depends on level of light penetration.
\end{abstract}

Key words: shallow tropical reservoir, nictemeral sampling, climatic and physical variables, phytoplankton dynamics, Brazil.

\section{RESUMO}

Variação dos codeterminantes climáticos e físicos sobre a comunidade fitoplanctônica em quatro amostragens nictemerais, nas quatro estações do ano, em um reservatório tropical raso, Sudeste, Brasil

Foram estudadas as variações espacial e temporal das características climáticas e físicas em um reservatório tropical raso situado na cidade de São Paulo e sua possível influência na dinâmica da comunidade fitoplanctônica. Foram retiradas amostras da coluna d'água (subsuperfície, $10 \% \mathrm{I}_{\mathrm{o}}, 1 \% \mathrm{I}_{\mathrm{o}}, 2$ $\mathrm{m}$ e fundo) a intervalos de 4 horas $(6,10,14,18,22,2$ e $6 \mathrm{~h})$ durante o verão (3-4 de março), outono (13-14 de junho), inverno (29-30 de agosto) e primavera (29-30 de novembro) de 1994. Concluiu-

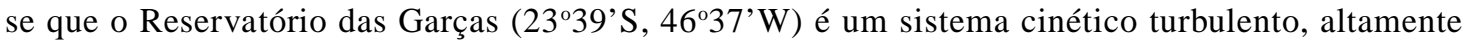
influenciado pelo vento, com estratificações térmicas que podem durar dias ou semanas, sofrendo períodos de mistura mais de uma vez ao ano. O padrão térmico desse tipo é comparável ao polimítico quente descontínuo. Do ponto de vista de suas propriedades ópticas, o reservatório foi classificado como um ecossistema de turbidez moderada, que diminui basicamente pelo aumento na concentração de feopigmentos na primavera. O reservatório é um sistema sob estresse e a intensidade do estresse 
para a comunidade fitoplanctônica deve-se à pouca penetração de luz, a qual aumenta do verão para a primavera.

Palavras-chave: reservatório tropical raso, amostragem nictemeral, variáveis climáticas e físicas, fitoplâncton, Brasil.

\section{INTRODUCTION}

The source of dissolved substances in a lake is external, but continuous production of organic materials in the environment depends on the circulation of the water column's upper and lower layers. The energy for such movement and material recycling comes from solar radiation and wind. Absorption and dissipation of solar radiation in the form of heat affects the thermal structure extensively as well as the stratification and circulation patterns of the water column (Beadle, 1974; Wetzel, 1993).

Wind distributes heat in water masses since its frictional force moves surface layers, generating mixtures and currents proportional to its intensity. Wind also affects cooling and surface evaporation rates, especially during periods of low atmospheric humidity (Beadle, 1974; Wetzel, 1993). Turbulence is maintained by the equilibrium between wind action force and, due to its molecular cohesion, water resistance to free movement. When wind force increases, a turbulent movement is produced which spreads vertically and gradually, thus creating whirlpools that break into smaller ones until they subdue to viscosity because of the dissipation rates generated. Consequently, variation of mixture intensity is more related to dissipation rates than to energy input (Reynolds, 1994).

Temperature interaction with density, turbulence, solar heat, winds, and mixtures affects phytoplankton ecology since it interferes with, among other factors, its spatial and temporal distribution, growth conditions, and reproduction and biomass rates (Olrik, 1994).

The present study aimed at determining and explaining the spatial and temporal climatic and physical variables of a shallow tropical reservoir and their possible influence on the ecology of the phytoplanktonic populations present. If there is an influence, changes in the phytoplankton community structure will follow alterations in the climatic and physical variables studied.

\section{STUDY AREA}

Garças Reservoir is located southeast of the city of São Paulo, in Parque Estadual das Fontes do Ipiranga $\left(23^{\circ} 39^{\prime} \mathrm{S}, 46^{\circ} 37^{\prime} \mathrm{W}\right)$. Its maximum depth is $4.60 \mathrm{~m}$; and the surface area is $97,067 \mathrm{~m}^{2}$ (Fig. 1).

The regional climate is of the Cwb type in Köppen's International Classification System, with an annual mean temperature of $19^{\circ} \mathrm{C}$, annual rainfall of $1,400 \mathrm{~mm}$, and predominantly SE winds. Remains of a tropical rain forest border the northern edge of the reservoir (Struffaldi-De-Vuono, 1985). The main free-floating macrophytes in the reservoir are Eichhornia crassipes (Mort.) Solms and Pistia sp.

The area in which the reservoir is located is of fluvial-lacustrine origin and probably from the Pliocene (Ab'Saber, 1956; Almeida, 1974). Soil type is lathosolic, poor in nutrients, strongly acid, with toxic levels of aluminum and potential characteristics for phosphorus fixation (Comissão de Solos, 1960; Struffaldi-De-Vuono, 1985).

\section{METHODS}

The present study is part of a larger one that aims at typification, monitoring, and recovery of the water bodies in the Biological Reserve of the Parque Estadual das Fontes do Ipiranga. Samples were taken with a one-liter Ruttner sampler at five water column depths (subsurface, $10 \% \mathrm{I}_{\mathrm{o}}, 1 \% \mathrm{I}_{\mathrm{o}}$, $2 \mathrm{~m}$, and bottom) at a single sampling station every four hours $(6: 00,10: 00,14: 00,18: 00,22: 00,2: 00$, and 6:00 h) during the summer (March 3-4, 1994), fall (June 13-14, 1994), winter (August 29-30, 1994), and spring (November 29-30, 1994).

Depths of $10 \% \mathrm{I}_{\mathrm{o}}$ and $1 \% \mathrm{I}_{\mathrm{o}}$ were calculated by multiplying the transparency value by 1.35 and 2.71 , respectively.

\section{Climatic co-determinants}

Methods used to estimate these co-determinants are shown in Table 1. 


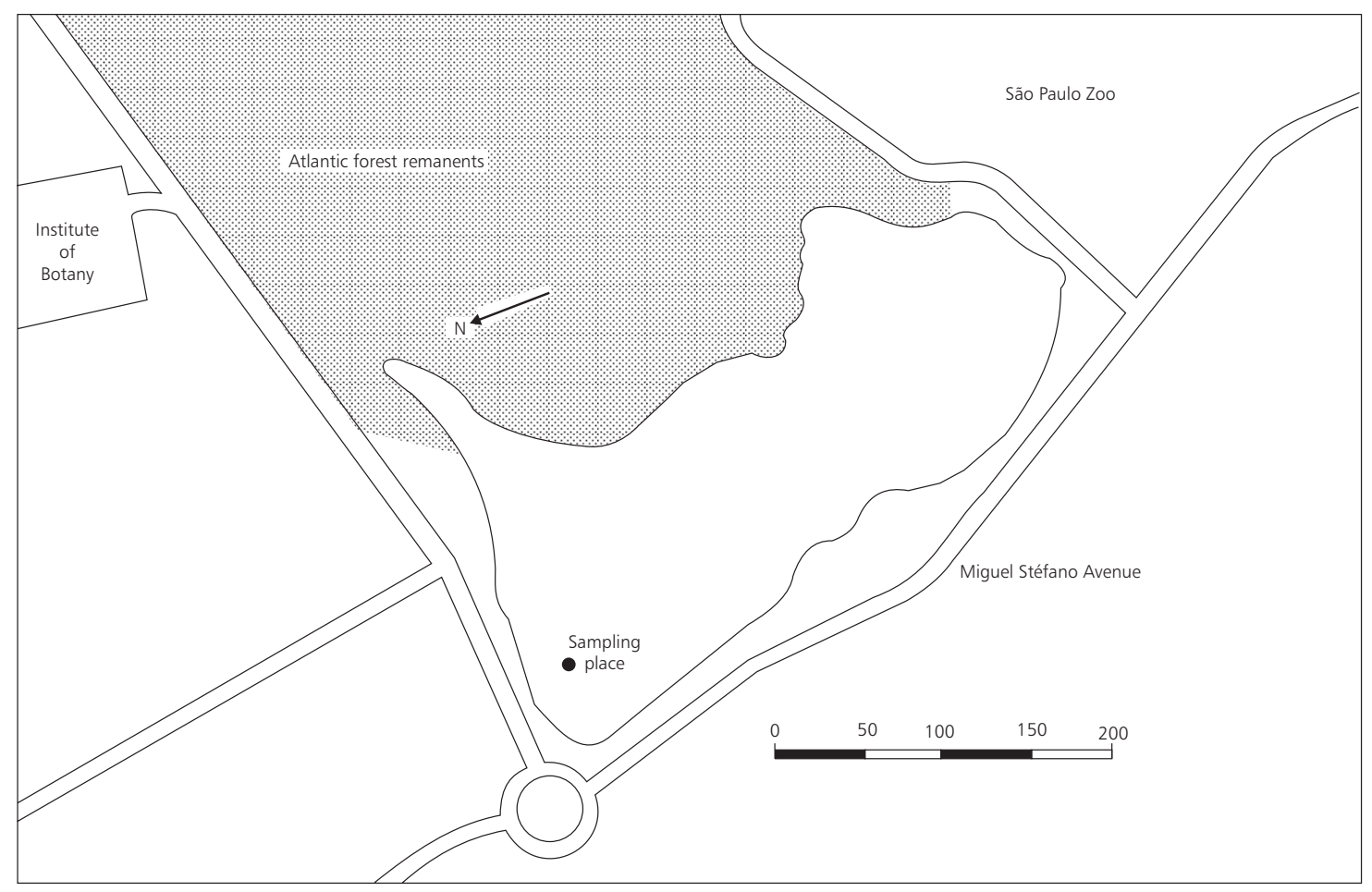

Fig. 1 - Garças Reservoir, São Paulo, Brazil. Localization of sampling station.

TABLE 1

Garças Reservoir, São Paulo, Brazil. Material and/or methods used to estimate climatic variables.

\begin{tabular}{|l|c|c|c|}
\hline \multicolumn{1}{|c|}{ Variable } & Unit & Material and/or method & Anotation \\
\hline Total solar radiation & $1 \mathrm{y}{ }^{*}$ & Robitzch fuess actinograph & Model 58D \\
\hline Air temperature & ${ }^{\circ} \mathrm{C}$ & Dry bulb thermometer & - \\
\hline Wind velocity & $\mathrm{m} \cdot \mathrm{s}^{-1}$ & Universal anemograph & Model 82A \\
\hline Pluvial precipitation & $\mathrm{Mm}$ & Ville de Paris pluviometer & \\
\hline
\end{tabular}

$*$ cal. $\mathrm{cm}^{-2} \cdot \mathrm{min}^{-1}$.

Values used were registered at the Alexander Postoiev Meteorological Station of the University of São Paulo. The station is $200 \mathrm{~m}$ from the collecting station. Dry and rainy seasons were defined based on Niemer's (1989) dry and sub-dry month criteria.

The relative position of a sampling day or monthly value in relation to a monthly or annual value was established in accordance with the following formulas:
Relative value of the day $(\%)=100$ [(value of a sampling day - monthly mean)/monthly mean].

Relative value of the month $(\%)=100$ [(monthly value - yearly mean)/yearly mean].

\section{Physical co-determinants}

Water column temperature was measured every $0.10 \mathrm{~m}$ using a FAC thermistor.

Water column relative thermal resistance (RTR) was calculated according to Hutchinson (1957). 
Turbidity (NTU) was obtained with a Micronal turbidimeter. Transparency was estimated with a 0.20 $\mathrm{m}$ diam. Secchi disc with alternating white and black quadrants. Vertical light attenuation was estimated by using Poole \& Atkins' (1929) coefficient.

Electric conductivity $\left(\mathrm{mS} . \mathrm{cm}^{-1}\right)$ was calculated with an Ambriex conductivimeter. Depth of the mixing zone $\left(\mathrm{Z}_{\text {mix }}\right.$ in $\left.\mathrm{m}\right)$ was estimated according to Reynolds (1984).

Friction speed $\left(\mathrm{u}^{*}\right.$ in $\left.\mathrm{m} \cdot \mathrm{s}^{-1}\right)$ in the mixing zone was calculated from wind speed (U) following Denmann \& Gargett (1983). The applied force or stress per unit area $\left(\mathrm{t}\right.$ in $\mathrm{kg} \cdot \mathrm{m}^{-1} \cdot \mathrm{s}^{-2}$ ) was estimated by multiplying the wind friction value by the adjacent media density (Denmann \& Gargett, 1983).

The stress applied on the surface bordering layer introduces a flow of kinetic energy $\left(J_{k}\right)$ from the highest to the lowest strata, which was estimated from $\mathrm{u}^{*}$.

$$
\mathrm{J}_{\mathrm{k}}=\mathrm{p}_{\text {water }}\left(\mathrm{u}^{*}\right)^{3}\left(\mathrm{~kg} \cdot \mathrm{s}^{-1}=\mathrm{Wm}^{2}\right) .
$$

The longest whirlpool formed $\left(l_{\mathrm{m}}\right.$ in $\left.\mathrm{m}\right)$ was calculated from the Von Karman constant (k) in accordance with Reynolds (1992). Intensity of the turbulence $\left(u^{*}\right)$ generated by wind stress $(t)$ is dissipated along the mixing layer $\left(\mathrm{Z}_{\text {mix }}\right)$. Dissipation rate of kinetic energy of turbulence $\left(\mathrm{E}\right.$ in $\left.\mathrm{m}^{2} . \mathrm{s}^{3}\right)$ was calculated according to Reynolds (1989).

The arithmetic mean was used as central position measurement. Absolute dispersion of data was calculated using the standard deviation, and relative dispersion by Pearson's variability coefficient (CV).

The degree of significance of all values for the studied variables among depths and hours was calculated for each sampling day with Analysis of Variance (ANOVA) to block design. Magnitude of hourly variation was established by Pearson's coefficient of variation. Assumptions for ANOVA were verified. In some cases, data were standardized by eliminating extreme values (outliers) and/or by logarithmic transformation (log). The tukey Test was used for means comparison.

Simple Linear Regression Analysis was used. Finally, Pearson Product-Moment Index was used, provided that involved variables were standardized.

\section{RESULTS AND DISCUSSION}

\section{Climatic co-determinants \\ Total solar radiation}

Radiation values were low during the summer (274 ly), increased during the fall (334 ly) and winter (394 ly), and decreased slightly during the spring sampling day (390 ly). Radiation values for the summer were not typical for that season since the day was hazy and rainy, with occasional sunshine. As a consequence, percentage values registered were relatively lower or higher than the month's mean $(-36.5 \%)$.

This variable displayed an annual pattern of progressive decrease up to the fall, with its minimum value in May (288 ly), then increasing until the summer when it reached its maximum (508 ly in December). Annual amplitude was 220 ly with a low CV (19.7\%) and the mean annual value 388.7 ly. This signifies that its seasonality was never as marked as would be expected in tropical and subtropical regions. In the United Kingdom, at $51^{\circ}$ $\mathrm{N}$, solar radiation varied almost $90 \%$ during a year (Viner \& Smith, 1973).

\section{Air temperature}

As anticipated, annual changes of air temperature were related to mean total solar radiation. The lowest value $\left(15.8^{\circ} \mathrm{C}\right)$ was registered in June and the highest $\left(23.8^{\circ} \mathrm{C}\right)$ in February. Annual amplitude was $8^{\circ} \mathrm{C}(\mathrm{CV}=13 \%)$ and the mean annual value, $19.7^{\circ} \mathrm{C}$.

Lowest air temperatures registered during the present study period occurred on the summer sampling day, on which the lowest and highest deviation values from the monthly mean $(-16 \%)$ were detected. During the winter, values were above the monthly mean $(20 \%)$ due to a radiation increase on that sampling day. Fall (-3\%) and spring (4\%) displayed slight deviations, but were close to the monthly mean. Lowest monthly variations occurred during the summer $(\mathrm{CV}=8.4 \%)$ and spring $(\mathrm{CV}=$ $13.6 \%)$, and the highest during the winter $(\mathrm{CV}=$ $19.5 \%)$ and fall $(\mathrm{CV}=18.8 \%)$. However, these variations should not be considered high since air temperature was quite homogeneous throughout the four sampling days.

Nictemeral variation of air temperature on each sampling day (Figs. 3-6) did not display fluctuation differing from what would be expected, i.e., gradual increase from 6:00 to 14:00 h, and decrease thereafter. The lowest nictemeral variation was observed during the summer $(\mathrm{CV}=6.2 \%)$ and spring $(\mathrm{CV}=13 \%)$, whereas the highest occurred during the fall $(\mathrm{CV}=29 \%)$ and winter sampling days $(\mathrm{CV}=20.7 \%)$. The highest air temperature values were measured at 14:00 $\mathrm{h}$ in the 
winter (Fig. 5) and at 18:00 h on the spring sampling day (Fig. 6), and not in the summer (Fig. 3), as would be expected.

\section{Rain precipitation}

During 1994, rain precipitation mean value was $109.6 \mathrm{~mm}$, with a relatively high CV (93.9\%) due to the great difference between the maximum (306.7 $\mathrm{mm}$ in December) and the minimum (5.5 $\mathrm{mm}$ in August) values. According to Niemer's criteria (1989), two rainy peaks occurred, one in February and the other in December. The rest of the year was sub-dry (June, July, and October) and dry (April, May, August, and September).

When the annual variation of air temperature $(\mathrm{CV}=13 \%)$ is compared to that of rain precipitation $(\mathrm{CV}=93.9 \%)$, one can see that the latter is 7.2 times more variable than the former. This completely agrees with the fact that in the tropics and subtropics seasonal variation of temperature is small when compared to that of rain precipitation (Baxter et al., 1965; Viner \& Smith, 1973; Ganf \& Horne, 1975; Payne, 1986; Barbosa \& Tundisi, 1988; Esteves, 1998; González, 1988).

Rain precipitation during the summer $(1.50 \mathrm{~mm})$ and spring sampling days $(0.20 \mathrm{~mm})$ were atypical and lower than the mean values $(-73.2 \%$ for the summer and $-95.6 \%$ for the spring; mean $=4.5 \mathrm{~mm})$. However, fall $(0.0 \mathrm{~mm})$ and winter $(0.0 \mathrm{~mm})$ fit the monthly trend.

\section{Wind}

The nictemeral pattern observed during the study period was similar to that displayed by the air temperature, i.e., it showed an increase from 6:00 to $14: 00 \mathrm{~h}$ and a decrease afterward.

All winds detected corresponded to "light breeze", whereas the high winds were measured during the humid months' sampling days (summer mean $=1.96 \mathrm{~m} \cdot \mathrm{s}^{-1}, \mathrm{CV}=17 \%$; autumn mean $=2.7$ $\left.\mathrm{m} . \mathrm{s}^{-1}, \mathrm{CV}=67.7 \%\right)$. The longest wind speed uniformity detected was during the summer $(\mathrm{CV}=$ $17 \%)$ and the lowest on June sampling days ( $\mathrm{CV}=$ $101.6 \%)$. The lowest wind speeds were measured during the fall (mean $=0.56 \mathrm{~m} \cdot \mathrm{s}^{-1}$ ), while during winter mean values were average $($ mean $=1.19$ $\left.\mathrm{m} \cdot \mathrm{s}^{-1}, \mathrm{CV}=46.1 \%\right)$.

Mean wind speed measured during the study year was 1.7 m.s ${ }^{-1}$ with low CV (17.3\%) and am- plitude $\left(1.1 \mathrm{~m} \cdot \mathrm{s}^{-1}\right)$. These values are indicative of low wind speed variation year round. Nevertheless, a slight tendency towards increase was observed during the humid months (summer and spring). According to the Beaufort's anenometric scale, all winds measured during the study period could be classified as light breezes (1.6-2.3 m.s. $\left.\mathrm{s}^{-1}\right)$.

Wind direction (Fig. 2) was against to the sampling station during the summer, unstable during the fall, and towards the sampling station during the winter and spring sampling days.

\section{Physical co-determinants}

Thermal behavior on the fall sampling day

During this day, with the exception of 14:00 and 22:00 $\mathrm{h}$, when the water column was thermally variable, the reservoir presented an inverted thermocline (Figs. 3, 7). According to Beadle (1974), such thermoclines are formed mainly due to the influence of a rainy and cloudy sky which reduces picnoclines. Such a condition was observed during the summer sampling day.

For Wetzel (1993), inverse stratification is readily destroyed by a very weak wind force. However, high surface temperatures and RTR (Fig. 4) inhibited mixing of the water due to wind action during the whole measurement period.

Air temperature values on that day were lower than those of the water temperature (Fig. 3). This led to a convectional cooling of the water by loss of surface heat through conduction to the atmosphere.

Consequently, the inverted thermocline progressively weakened between 6:00 and 22:00 h due to the already mentioned loss of convectional heat and the increase in wind speed, which increased the cooling rate of evaporation especially during the hours of low atmospheric humidity (Beadle, 1974).

Frictional forces $\left(\right.$ mean $\left.=5.96 \times 10^{3} \mathrm{~kg} \cdot \mathrm{m}^{-1} \cdot \mathrm{s}^{-2}\right)$ and kinetic energy (mean $=1.5 \times 10^{-5} \mathrm{~kg} \cdot \mathrm{s}^{-3}$ ) from wind action on the summer sampling day presented relatively high values. Despite the fact that the dissipation rate was the lowest of all sampling days $\left(\right.$ mean $\left.=3.4 \mathrm{~m}^{-2} \cdot \mathrm{s}^{-3}\right)$, the high RTR registered a few centimeters below the surface (Fig. 3) inhibited the action of the generated turbulence to such an extent that the water from the surface layers was not displaced at the moment that inverse stratification occurred. 

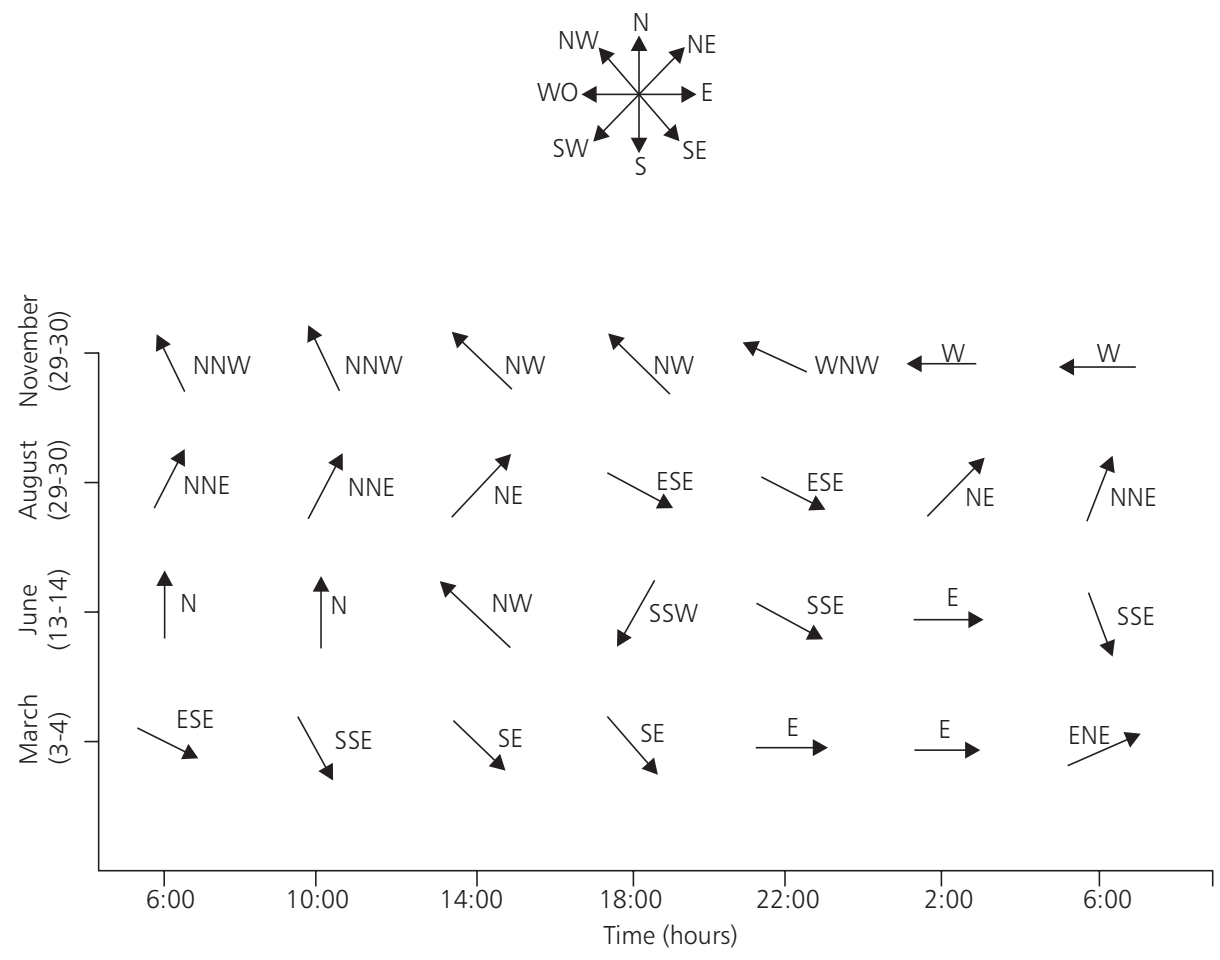

Fig. 2 - Nictemeral variation of wind direction during each sampling day at Garças Reservoir.
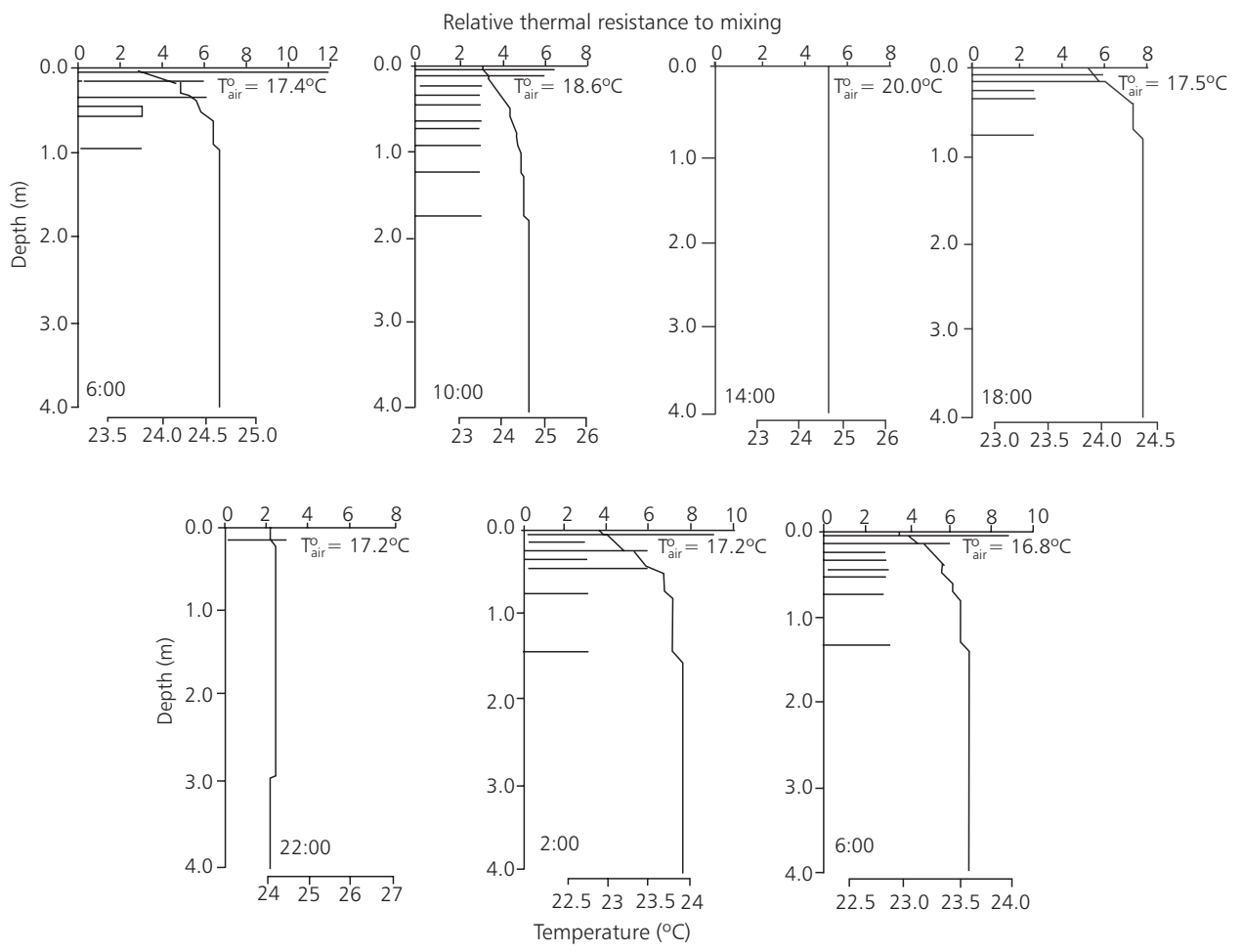

Fig. 3 - Nictemeral variation of air temperature $\left(\mathrm{T}_{\text {air }}\right)$, water temperature, and RTR profiles during the fall sampling day (3-4 March 1994) at Garças Reservoir. 
The latter process was reinforced by the wind direction, which was SE during most of the sampling period (Fig. 2) and always contrary to the sampling station. This could mean that mixing of the water column occurred in the opposite extreme of reservoir, where depths are lower and wind force generates its maximum effect.

\section{Thermal behavior on the winter sampling day}

As shown in Figs. 4 and 7, a weak thermal gradient caused by convectional cooling of the water was observed. At those hours, loss of heat was more accentuated (a difference of $8.2^{\circ} \mathrm{C}$ between atmospheric and water temperature), and the process was favored by the wind blowing towards the sampling station (Fig. 2). At the end of the sampling period $(6: 00 \mathrm{~h})$ a similar event occurred when the difference between atmospheric and water temperatures reached $6.8^{\circ} \mathrm{C}$. With the exception of the thermal gradients present between 14:00 and 22:00 $\mathrm{h}$, all remaining gradients did not cause enough density differences $\left(>0.02 \mathrm{~kg} \cdot \mathrm{m}^{-3} \cdot \mathrm{m}^{-1}\right.$, according to Reynolds, 1984) to be considered seasonal thermoclines of any sort.
A thermal surface gradient began to form starting at $14: 00 \mathrm{~h}$ and progressively sank up to 22:00 h. Loss of heat by convection was accentuated at 18:00 and 22:00 $\mathrm{h}$ due to a decrease of air temperature that caused a difference of $11^{\circ} \mathrm{C}$ between 14:00 and 6:00 h (Fig. 4). That loss was, however, strengthened by the wind direction which was blowing contrary to the sampling station (Fig. 2). In spite of the gentle winds, this process caused a net loss of heat that, according to Reynolds (1989), allowed the establishment of a uniform surface layer deepened by the rapid loss of convectional heat that resulted in the sinking of the cooler layers to generate a partial mixture of the water at 2:00 h.

Due to the low wind speed, lower forces $\left(\right.$ mean $\left.=1.04 \times 10^{-3} \mathrm{~kg} \cdot \mathrm{m}^{-1} \cdot \mathrm{s}^{-2}\right)$, frictional velocities (mean $\left.=7.43 \times 10^{-4} \mathrm{~m} \cdot \mathrm{s}^{-1}\right)$, and kinetic energy flow $\left(\right.$ mean $\left.=2.12 \times 10^{-6} \mathrm{~kg} . \mathrm{s}^{-3}\right)$ were generated. Nevertheless, due to the decreasing influence of the RTR (Fig. 4), relatively large whirlpools were formed (mean $=0.97 \mathrm{~m}$ ) with considerable water column penetration due to the low rate of dissipative energy $\left(\right.$ mean $\left.=1.28 \times 10^{-8} \mathrm{~m}^{-2} \cdot \mathrm{s}^{-3}\right)$.

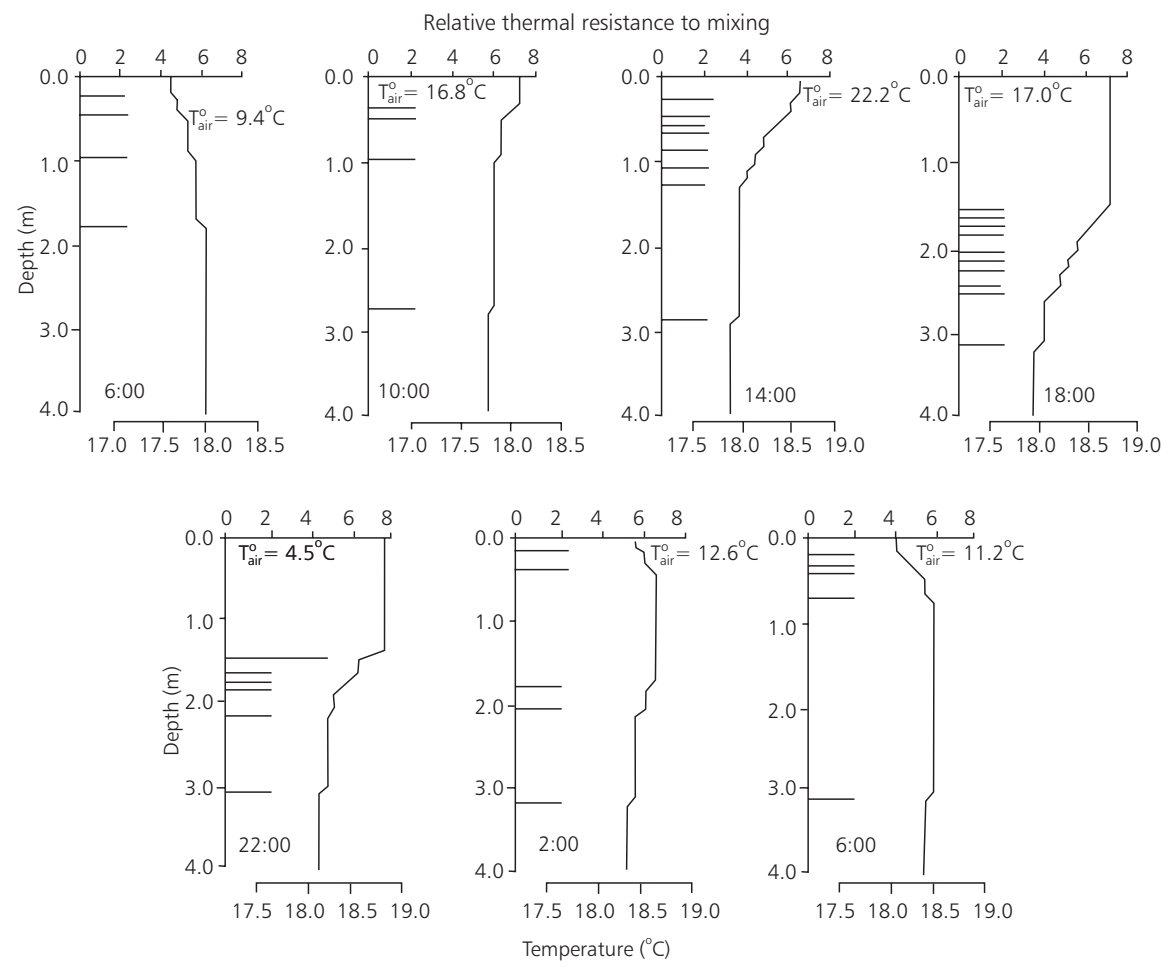

Fig. 4 - Nictemeral variation of air temperature $\left(\mathrm{T}_{\text {air }}\right)$, water temperature, and RTR profiles during the winter sampling day (13-14 June 1994) at Garças Reservoir. 
This explains the thermocline sinking between 14:00 and 22:00 $\mathrm{h}$ and the deep mixing at 2:00 and 6:00 h.

\section{Thermal behavior on the spring sampling day}

On this day (Figs. 5, 7C), the thermal behavior of the reservoir began a change that continued on to the spring sampling day. First, the water column presented a partial mixing at $6: 00 \mathrm{~h}$ and then a greater degree of stability was observed. Thermal gradients progressively strengthened throughout the day until well-defined surface thermoclines were formed at 14:00 and 22:00 h, lasting until the next day. As of 2:00 h, the thermoclines slowly weakened due to the convectional cooling of surface water (Fig. 7C).

Due to an increase in wind speed (mean $=$ $1.19 \mathrm{~m} . \mathrm{s}^{-1}$ ) and wind displacement towards the sampling station, friction force $($ mean $=1.45 \times$ $10^{-3} \mathrm{~kg} \cdot \mathrm{m}^{-1} \cdot \mathrm{s}^{-2}$ ), friction velocity (mean $=1.20 \times 10^{-3}$ $\mathrm{m} . \mathrm{s}^{-1}$ ), and kinetic energy flow (mean $=3.69 \times 10^{-6}$ $\left.\mathrm{kg} . \mathrm{s}^{-3}\right)$ means were slightly greater. In contrast, whirlpools, mean value was lower $($ mean $=0.31 \mathrm{~m})$ than during the fall sampling day (mean $=0.97 \mathrm{~m})$. RTR increase on that day (Fig. 5), as well as the dissipative energy increase $\left(2.41 \times 10^{-8} \mathrm{~m}^{-2} \cdot \mathrm{s}^{-3}\right)$ during the winter (1.88 greater than in the fall), were responsible for the much lower penetration of the already mentioned whirlpools in the reservoir.

\section{Thermal behavior on the summer sampling day}

Since solar radiation, air temperature, and wind speed values increased from winter to spring, so did kinetic energy flow (mean $=8.28 \times 10^{-4} \mathrm{~kg} \cdot \mathrm{s}^{-3}$ ), friction forces $\left(\right.$ mean $\left.=1.28 \times 10^{-2} \mathrm{~kg} \cdot \mathrm{m}^{-1} \cdot \mathrm{s}^{-2}\right)$, friction velocity $\left(\right.$ mean $\left.=3.37 \times 10^{-3} \mathrm{~m} \cdot \mathrm{s}^{-1}\right)$, whirlpool size $(0.54 \mathrm{~m})$, dissipative energy $(3.52 \times$ $10^{-7} \mathrm{~m}^{2} \cdot \mathrm{s}^{-3}$ ), and RTR. Dissipative energy was 14.7 times greater in the spring than in winter, 112.1 times greater than in fall, and 27.5 times than in summer.

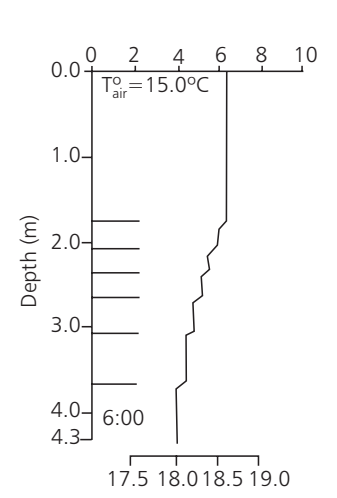

Relative thermal resistance to mixing
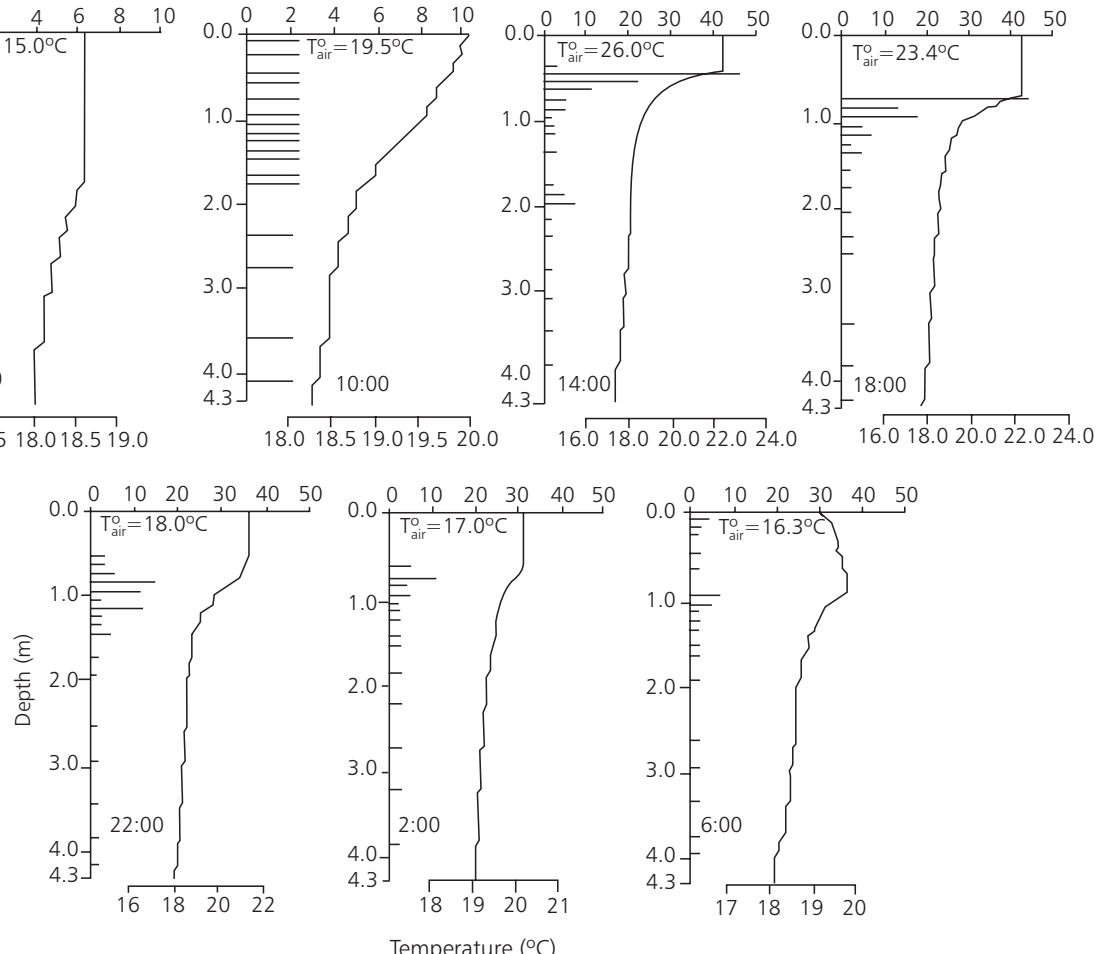

Fig. 5 - Nictemeral variation of air temperature $\left(\mathrm{T}_{\text {air }}\right)$, water temperature, and RTR profiles during the spring sampling day (29-30 August 1994) at Garças Reservoir. 
The thermal gradient that emerged in winter was accentuated on this day, forming well defined surface thermoclines (Figs. 6, 7D), which decreased in height from 6:00 to 14:00 $\mathrm{h}$ due to a net heat gain by the gradual increase of solar radiation and air temperature towards the end of the afternoon (Fig. 6). This fact caused a decrease in convectional cooling and, at the same time, an increase of the floating force flow as a result of a decrease in the surface layer density. On that day there was a considerable decrease of oxygen concentration at the bottom of reservoir, as well as an increase in conductivity, and nitrogen and total phosphate concentrations (Table 2). It was possible to conclude that the thermoclines that formed lasted comparatively longer.

Another factor possibly influencing thermal stability on that day was the constant wind sampling-stationward (Fig. 2) and displacing the blooming Microcystis masses in the direction the station. As a result, local concentration of suspended material increased and the euphotic zone depth decreased. According to Kirk (1985), for a specific wind pattern an increase in the amount of suspended material induces an increase in the subsurface layer's heat absorption and, consequently, an increase of thermal stability and a decrease of mixing probability.

It can be concluded that Garças Reservoir is a turbulent kinetic environment, highly influenced by wind forces, with diurnal stratification that can last days or weeks (Tett, 1990). Furthermore, the reservoir presents more than one mixing period during the year. A thermal pattern of this kind coincides with what Lewis Jr. (1983) described as warm discontinuous polymictic.

\section{Optical properties}

It can be observed in Table 3 and Fig. 8A that the light vertical attenuation coefficient varied from $2.61 \mathrm{~m}^{-1}$ on the fall sampling day to $8.50 \mathrm{~m}^{-1}$ on the spring day. This corresponds to an amplitude variation of $5.89 \mathrm{~m}^{-1}$, which can be considered high and was due to the difference in surface radiation intensity and to the different conditions of the lake on each sampling day. The CV among hours on each sampling day was generally low with a small increase in the winter $(10.1 \%)$ and spring $(12.4 \%)$.

Relative thermal resistance to mixing
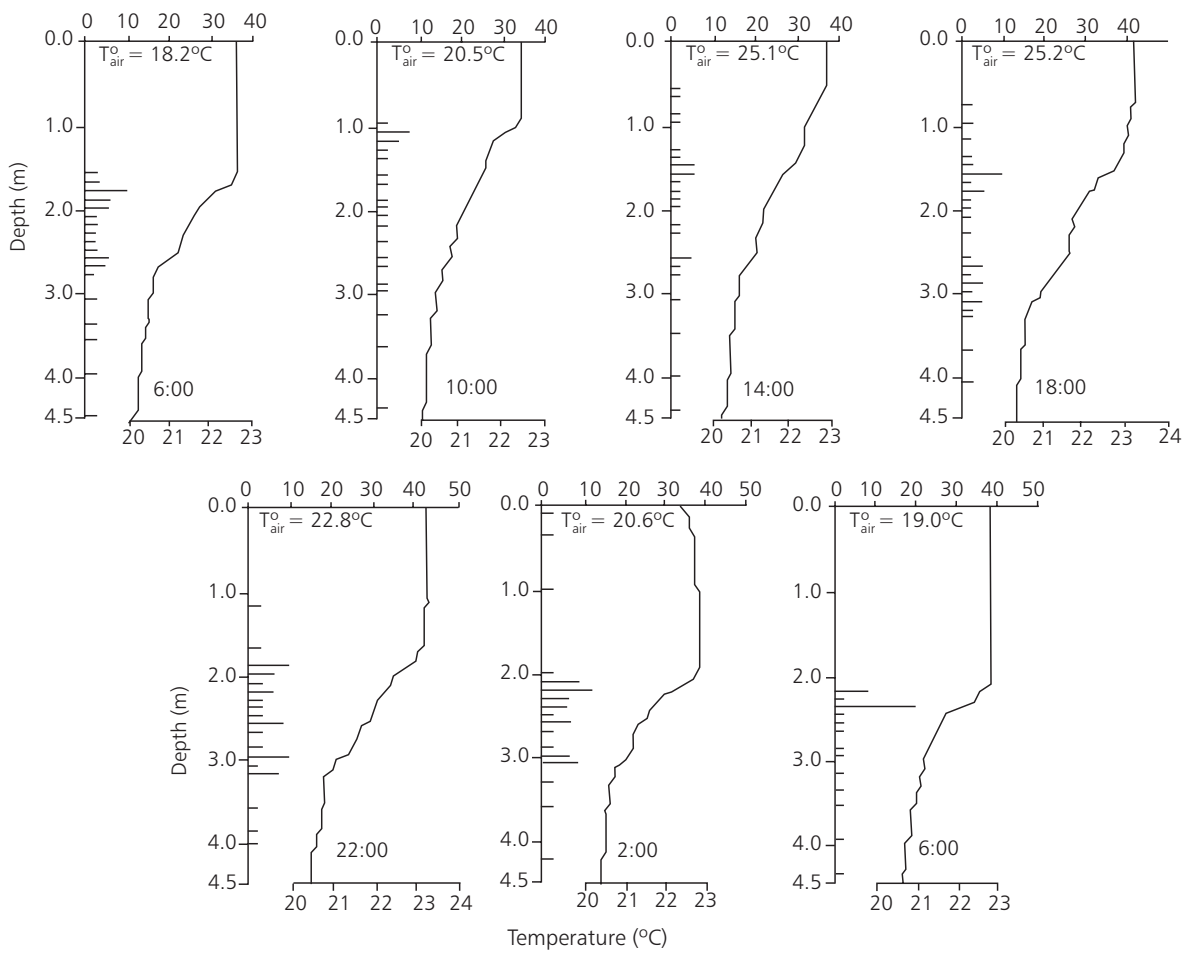

Fig. 6 - Nictemeral variation of air temperature $\left(\mathrm{T}_{\text {air }}\right.$ ), water temperature, and RTR profiles during the summer sampling day (29-30 November 1994) at Garças Reservoir. 


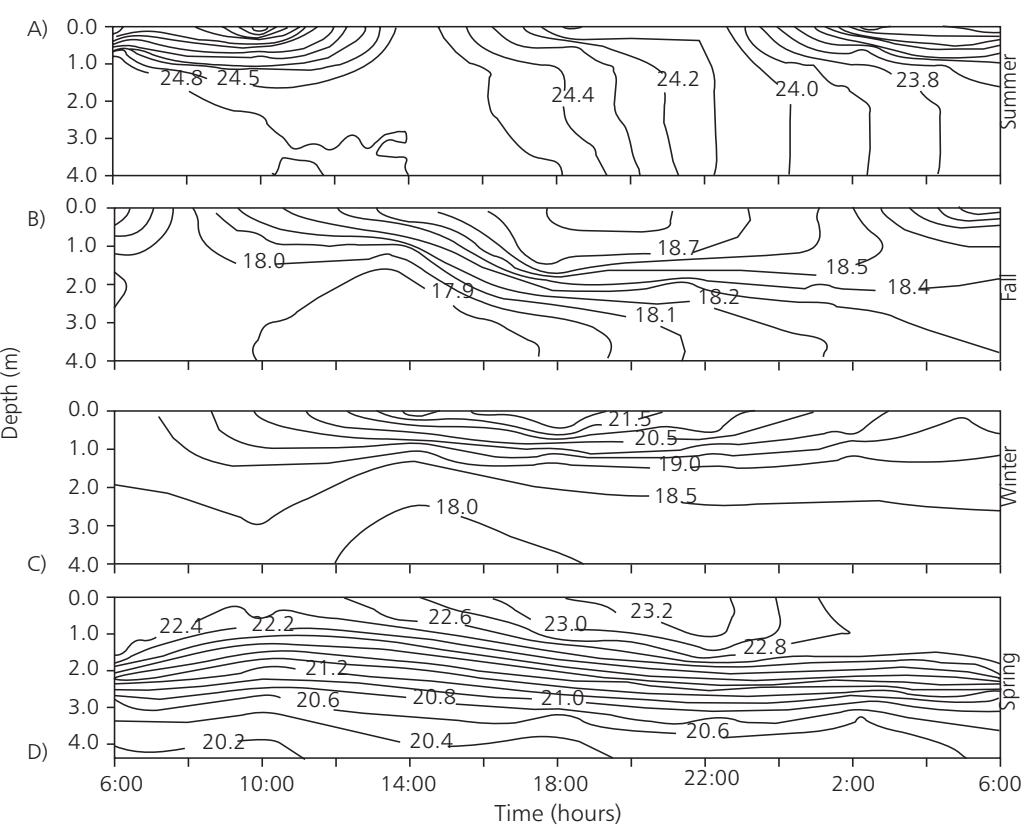

Fig. 7 - Nictemeral variation of temperature isolines on each sampling day at Garças Reservoir.

TABLE 2

Low values for electric conductivity $\left(\mathrm{mS} . \mathrm{cm}^{-1}\right)$, dissolved oxygen $\left(\mathrm{mgO}_{2} \cdot \mathrm{L}^{-1}\right)$, total nitrogen $\left(\mathrm{mgN}-\mathrm{NO}_{3} \cdot \mathrm{L}^{-1}\right)$, and total phosphorus $\left(\mathrm{mgP}-\mathrm{PO}_{4} \cdot \mathrm{L}^{-1}\right)$ on each sampling day at Garças Reservoir.

\begin{tabular}{|l|c|c|c|c|}
\hline Variable & Summer & Fall & Winter & Spring \\
\hline Electric conductivity & 150.0 & 141.0 & 150.9 & 161.4 \\
\hline Dissolved oxygen & 0.72 & 5.35 & 1.83 & 0.81 \\
\hline Total nitrogen & 1531.79 & 1053.83 & 884.95 & 831.67 \\
\hline Total phosphorus & 41.85 & 42.30 & 42.37 & 81.76 \\
\hline
\end{tabular}

Consequently, differences in $\mathrm{k}$ (logarithmically transformed) among the different sampling hours were not considered statistically different $(\mathrm{F}=0.62, \mathrm{p}=0.5694)$.

When sampling days (Table 3 ) are considered, the CVs were comparatively higher and oscillated between $46.9 \%$ and $64.8 \%$. This shows high heterogeneity in radiation attenuation throughout days, which was verified by the highly significant differences among them $(\mathrm{F}=83.03, \mathrm{p}=$ 0.0000). Fig. 8A shows that during the spring sampling day light attenuation was comparatively greater. In the same figure, one can observe that during each sampling day values were dispersed, as would be expected since this variable changes little when measured at short intervals.
Regression analysis shows no relationship between $\mathrm{k}$ and active chlorophyll concentration $(\mathrm{r}=0.14, \mathrm{p}=0.6641, \mathrm{n}=12)$. This was due to a decrease of chlorophyll that resulted from the increase in Microcystis colonies and phaeopigment in concentration in the reservoir. The $\mathrm{k}$ coefficient was highly and positively related to turbidity $(\mathrm{r}=$ $-0.90, \mathrm{p}=0.00006, \mathrm{n}=12$ ). At the same time, turbidity was negatively affected by phytoplankton $(\mathrm{r}=-0.33, \mathrm{p}=0.00070, \mathrm{n}=140)$ and Cyanophyceae density $(\mathrm{r}=-0.88, \mathrm{p}=0.00000, \mathrm{n}=140)$, as well as positively affected by phaeopigments $(\mathrm{r}=0.88, \mathrm{p}=0.00000, \mathrm{n}=140)$.

Fig. $8 \mathrm{~B}$ shows that turbidity increased from the summer sampling day (mean $=19.8 \mathrm{NTU}$ ) to the spring day (mean $=36.3 \mathrm{NTU})$. These values 
define semi-turbid water according to Bruton (1985) scale (semi-turbid water $=10-50 \mathrm{NTU}$, turbid $=50-80 \mathrm{NTU}$, highly turbid $=780 \mathrm{NTU}$ ). ANOVA reveals highly significant differences among sampling days $(\mathrm{F}=14.84, \mathrm{p}=0.0000, \mathrm{n}=$ $12)$, but not among sampling hours $(\mathrm{F}=0.30, \mathrm{p}=$ $0.7484, \mathrm{n}=12$ ). Mean comparison (Fig. $8 \mathrm{~B}$ ) showed spring sampling day to be unlike all others.

Low influence of phytoplankton density on turbidity $\left(\mathrm{r}^{2}=10.9 \%, \mathrm{p}=0.00070\right)$ is probably because even though planktonic components were part of the suspended material, the latter was mostly inorganic (tripton) and came from the watershed soil or from sediment re-suspension by turbulence (Kirk, 1985). As for the above, $r$ values were negative for all algal groups presently considered ( $\mathrm{r}$ for Euchlorophyceae $=-0.77, \mathrm{r}$ for Cryptophyceae $=$ $-0.60, \mathrm{r}$ for Diatomophyceae $=-0.75$, and $\mathrm{r}$ for flagellates $=-0.66$; all with $\mathrm{p}=0.00000$ ) with the exception of Cyanophyceae $(r=0.70, p=0.00000)$. This last datum demonstrates the greater influence of Cyanophyceae on turbidity due to Microcystis bloom during the spring.

The negative value of $r$ in relation to turbidity and $\mathrm{Z}_{\text {eup }}: \mathrm{Z}_{\text {aph }}$ ratio $(\mathrm{r}=-0.90, \mathrm{p}=0.00000)$ is a consequence of the numeric increase of Cyanophyceae, since when they increased the ratio value dropped due to a decrease in the height of the euphotic zone and an increase in the aphotic zone depth.

According to Kirk $(1975,1976)$, cell size and shape, as well as pigment distribution in the cell, can produce a considerable difference in the amount of light interception. In general, the bigger the cell or colony, the lesser the amount of light gathered per unit of biomass. However, because this effect is partially a demand of the surface:volume ratio, the shape of the cell is also important too. In this way, for a given cell or colony of a certain volume, the longer they are, the more light they will gather since the smaller the size of the suspended particles, the greater the effect on turbidity.

On one hand, at Garças Reservoir Microcystis colonies are quite large and, consequently, their participation in turbidity is very low, but when the size of the isolated cells is considered, their participation in turbidity increased. On the other hand, however, these algae can accumulate carothene, making them darker in color and, consequently, attenuating the negative effects of surface radiation (Kirk, 1976). The latter mechanism functions as a sort of protecting shield against ultraviolet radiation, most of the effects of which upon chlorophyll are thus diminished (Kirk, 1975; Pearl et al., 1983).
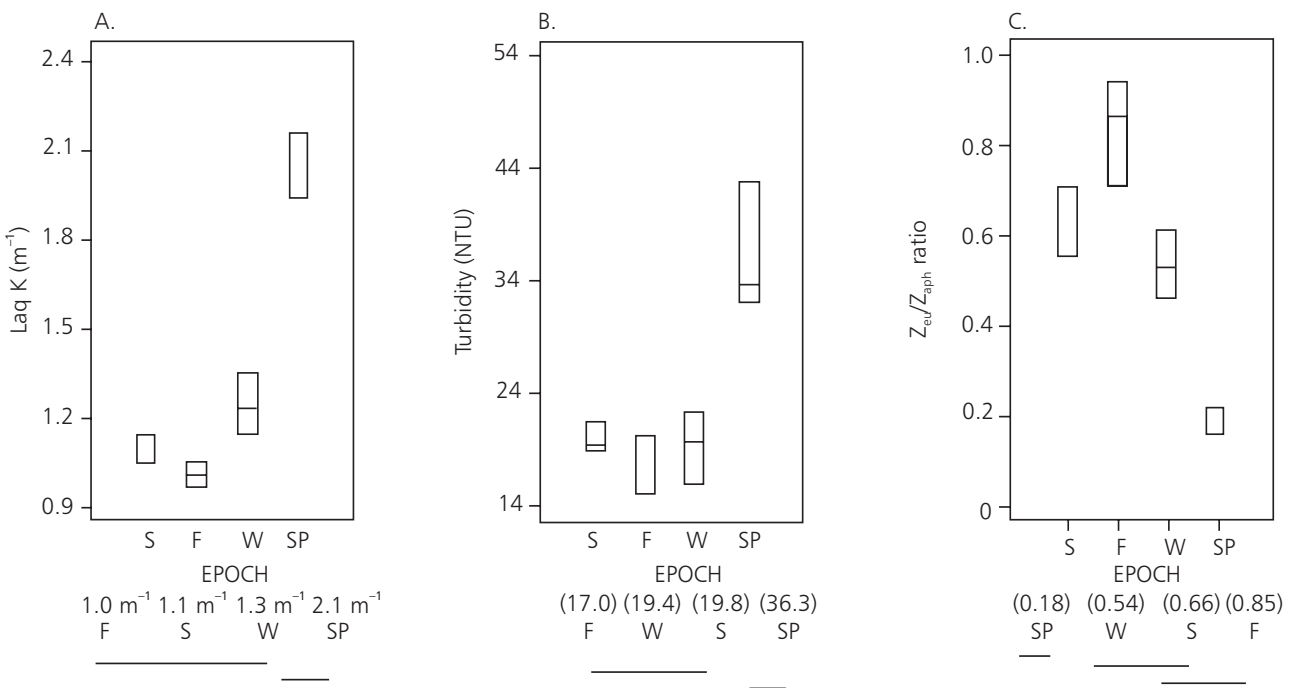

Fig. 8 - Seasonal variation and mean comparisons of (A) vertical attenuation coefficient, (B) turbidity, and (C) $\mathrm{Z}_{\text {euph }}: \mathrm{Z}_{\text {aph }}$ ratio at Garças Reservoir. $\mathrm{S}=$ summer sampling day; F = fall sampling day; $\mathrm{W}=$ winter sampling day; and $\mathrm{SP}=$ spring sampling day. 
TABLE 3

Basic matrix of mean and relative dispersion values of light vertical attenuation coefficient (k) for each sampling day at Garças Reservoir.

\begin{tabular}{|l|c|c|c|c|c|c|}
\hline \multicolumn{1}{|c|}{ Time } & Summer & Fall & Winter & Spring & Mean value & CV (\%) \\
\hline $6: 00$ & 2.83 & 2.83 & 3.09 & 8.50 & 4.31 & 64.8 \\
\hline $10: 00$ & 3.09 & 2.61 & 3.78 & 8.50 & 4.49 & 60.3 \\
\hline $14: 00$ & 3.09 & 2.74 & 3.40 & 6.80 & 4.00 & 46.9 \\
\hline Mean value & 3.00 & 2.72 & 3.42 & 7.93 & 4.27 & \\
\hline CV $(\%)$ & 5.0 & 4.1 & 10.1 & 12.4 & & \\
\hline
\end{tabular}

Size of Microcystis cells does not increase radiation dispersion. Instead, their color increases radiation absorption, hence inhibiting its path and increasing light attenuation. Additionally, aerotopes present in these cells may also have the effect of tiny protective shields (Shear \& Walsby, 1975), which inhibit light passage. Furthermore, algae abundance produces mutual shading (biotic turbidity). These mechanisms can be considered greatly responsible for the high $\mathrm{k}$ values measured during the spring sampling day, since the polymictic pattern, that could have increased the amount of suspended material in the water, decreased during this season. This can be confirmed by the decrease in concentration of suspended material from the winter sampling day (17.5 mg.. $\mathrm{L}^{-1}$ ) to the spring one (7.5 mg.. $\mathrm{L}^{-1}$ ) (Ramírez, 1994, unpublished data). In spite of its small contribution, another mechanism responsible for the high $\mathrm{k}$ values would be the increase of phaeopigment concentrations $(r=0.88, p=0.00000)$ due to the beginning of the decline of the Microcystis bloom that releases degraded pigments, thus increasing light attenuation due to the water $\left(\mathrm{k}_{\mathrm{w}}\right)$ (Esteves, 1998). However, this contribution is low.

The $\mathrm{k}$ values on the other sampling days, despite being lower than on the spring day (Fig. 8A), still display high attenuation possibly due to a more pronounced polymixis on these days, which would increase abiogenic suspension responsible for decreasing in radiation with depth in shallow lakes (Dokulil, 1994). However, abiotic concentrations which contribute to the suspended material in this lake were low and as shown by (1) the greenish color of the water, which holds moderate levels of humic substances (Kirk, 1985), and (2) the seston concentration $\left(42.5 \mathrm{mg} . \mathrm{L}^{-1}\right.$ in the summer, $5 \mathrm{mg}$. $\mathrm{L}^{-1}$ in the fall, $17.5 \mathrm{mg} \cdot \mathrm{L}^{-1}$ in the winter, and 7.5 $\mathrm{mg} . \mathrm{L}^{-1}$ in the spring), which is considered standard by Sawyer \& McCarthy (1978). Regarding the $\mathrm{k}$ values, the $Z_{\text {euph }}: Z_{\text {aph }}$ ratio presented higher $C V$ values among the sampling days than among hours (Table 4). As a consequence, significant differences were found among sampling days $(\mathrm{F}=30.58, \mathrm{p}=0.0005$, $\mathrm{n}=12)$, but not among hours $(\mathrm{F}=0.63, \mathrm{p}=0.5666)$. Mean comparison allowed the conclusion that the spring sampling day was distinct from all others (Fig. 8C), a difference that was probably due to the increase of biogenic substances, $\mathrm{k}$ values, and radiation attenuation as explained before. These increments decreased the height of the photic zone so that the depth of the lighted zone was negatively correlated and dependent on the turbidity variation $(\mathrm{r}=-0.93, \mathrm{p}=0.00001, \mathrm{n}=12)$.

Fig. 9C also shows that the mentioned ratios were lower than the unit, which implies the existence of a more lighted aphotic zone. This observation agrees with Bruton (1985) in the sense that the major ecological impact of the suspended material is to reduce the euphotic zone and increase the aphotic one, which means a greater area of oxygen consumption, organic matter mineralization, and nutrient release. All the latter have the potential to increase phytoplankton production.

According to Tett (1990), phytoplankton undergoes greater fluctuations in the region of diurnal thermoclines due to subsurface light exposure as a result of transport by large whirlpools, which can be demonstrated by the $\mathrm{Z}_{\text {mix }}: \mathrm{Z}_{\text {aph }}$ ratio. It would be expected that such behavior be more pronounced during the first two sampling days, and decrease during winter and spring. Nevertheless, due to the complex thermal profile of the summer sampling day, measured values for the height of the mixing zone were not those expected. 
TABLE 4

Mean and relative dispersion values of $Z_{\text {euph }}: Z_{\text {aph }}$ ratio during light hours of each sampling day at Garças Reservoir.

\begin{tabular}{|l|c|c|c|c|c|c|}
\hline \multicolumn{1}{|c|}{ Time } & Summer & Fall & Winter & Spring & Mean value & CV $(\%)$ \\
\hline 06:00 & 0.56 & 0.72 & 0.62 & 0.16 & 0.51 & 47.7 \\
\hline 10:00 & 0.71 & 0.95 & 0.46 & 0.16 & 0.57 & 59.4 \\
\hline 14:00 & 0.71 & 0.87 & 0.53 & 0.21 & 0.58 & 48.8 \\
\hline Mean value & 0.66 & 0.85 & 0.54 & 0.18 & & \\
\hline CV $(\%)$ & 13.1 & 13.8 & 14.9 & 16.3 & & \\
\hline
\end{tabular}

Values of the mentioned ratio decreased from 6:00 to $14: 00 \mathrm{~h}$ on the three other sampling days (Table 5) because of a progressive increase of the height of the photic zone by a successive increase of total solar radiation incidence. It could also be observed from Table 5 that the CVs were higher than $45 \%$ for both sampling days and hours. This shows the great variability of the gathered data, which reflects light changes either in the subaquatic or external environment. Increasing values of $Z_{\text {mix }}: Z_{\text {euph }}$ towards the spring sampling day are due to a decrease in the height of $Z_{\text {euph }}$, as discussed elsewhere. It can be then concluded that during the first morning hours of all sampling days (Table 5 ), the phytoplankton community was subjected to aquatic darkness which decreased during the day through the combined effect of radiation input, its attenuation, and the increase of air temperature.

It seems logical that these conditions would subject the algal community to different light intensities during the very same day.

These differences would constitute selective pressure favoring adaptations that would decrease sinking rates and allow active migration among different depths, especially to layers offering suitable light, temperature, and nutrient conditions (Reynolds \& Walsby, 1975). In general, turbid and turbulent waters in the mixing zone are aphotic and as extensive as the photic zone (Dokulil, 1994), which is not exactly the case of Garças Reservoir since its behavior depends on the season of the year and on the sampling hour. From the optical properties standpoint, Garças Reservoir may be classified as a moderately turbid ecosystem basically reduced by biotic factors and increases in phaeopigment concentration towards the spring sampling day. Despite this, it can be stated that the reservoir an ecosystem undergoing mild stress, the degree of which affects the phytoplankton community is depends on light penetration increases from summer to spring.

Acknowledgments - Senior author wishes to acknowledge Red Latinoamericana de Botánica for doctoral fellowship; to the personnel of the Phycology Section of the Instituto de Botânica, especially to José Domingos, Naiza Nogueira, Andrea Tucci do Nascimento Moura, and Elizete Mitico, for their valuable help in the laboratory and field work; to the Instituto de Biociências of the University of São Paulo and to the Biology Department of the University of Antioquia for their support.

TABLE 5

Mean and relative dispersion values for $\mathrm{Z}_{\text {mix }}: \mathrm{Z}_{\text {euph }}$ ratio during lighted hours of each sampling day at Garças Reservoir.

\begin{tabular}{|l|c|c|c|c|c|}
\hline \multicolumn{1}{|c|}{ Time } & Fall & Winter & Spring & Mean value & CV (\%) \\
\hline $06: 00$ & 2.22 & 1.03 & 2.83 & 2.03 & 45.2 \\
\hline 10:00 & 2.05 & 0.22 & 1.67 & 1.31 & 73.5 \\
\hline 14:00 & 0.21 & 0.27 & 0.67 & 0.38 & 65.2 \\
\hline Mean value & 1.49 & 0.51 & 1.72 & & \\
\hline CV $(\%)$ & 74.6 & 89.6 & 62.7 & & \\
\hline
\end{tabular}




\section{REFERENCES}

AB'SABER, A., 1956, A terra paulista. Bolm Paul. Geogr., 23: 5-38.

ALMEIDA, F. F. M., 1974, Fundamentos geológicos do relevo paulista. Inst. Geogr. Univ. S. Paulo: ser. theses monogr., 14: 5-99.

BARBOSA, F. A. R. \& TUNDISI, J. G., 1988, Diel variations in a shallow tropical brazilian lake, 1: the influence of temperature variation on the the distribution of dissolved oxygen and nutrients. Arch. Hydrobiol., 116: 333344.

BAXTER, R. M., PROSSER, M. V., TALLING, J. F. \& WOOD, R. B., 1965, Stratification in tropical African lakes at moderate altitudes (1,500 to 2,000 m). Limnol. Oceanogr., 10: 510-520.

BEADLE, L. C., 1974, The inland waters of tropical Africa: an introduction to tropical Limnology. Longman Group Limited, London, 365p.

BRUTON, M. N., 1985, The effects of suspensoids on fish. Hydrobiologia, 125: 221-242.

COMISSÃO DE SOLOS, 1960, Levantamento de reconhecimento dos solos do Estado de São Paulo. Bolm Serv. Nac. Pesq. Agron., 12: 1-634.

DENMANN, K. L. \& GARGETT, A. E., 1983, Time and space scales of vertical mixing and advection of phytoplankton in the upper ocean. Limnol. Oceanogr., 28: 801-815.

DOKULIL, M. T., 1994, Environmental control of phytoplankton productiviy in turbulent turbid systems. Hydrobiologia, 289: 65-72.

ESTEVES, F. A., 1998, Fundamentos de Limnologia. Editora Interciência/Finep, Rio de Janeiro, 602p.

GANF, G. G. \& HORNE, A. J., 1975, Diurnal stratification, photosynthesis and nitrogen fixation in a shallow, equatorial lake (Lake George, Uganda). Freshw. Biol., 5: 1339.

GONZÁLEZ, A., 1988, El plancton de las aguas continentales. Secretaría General de la Organización de los Estados Americanos, Washington, DC, 130p.

HUTCHINSON, G. E., 1957, A Treatise on Limnology, 1: geography, physics and chemistry. John Wiley and Sons, Inc., New York, 1015p.

KIRK, J. T. O., 1975, A theoretical analysis of the contribution of algal cells to the attenuation of light within natural waters, 2: spherical cells. New Phytol., 75: 21-36.

KIRK, J. T. O., 1976, A theoretical analysis of the contribution of algal cells to the attenuation of light in natural waters, 3: cylindrical and spheroidal cells. New Phytol., 77: 341-358

KIRK, J. T. O., 1985, Effects of suspensoids (turbidity) on penetration of solar radiation in aquatic ecosystems. Hydrobiologia, 125: 195-208.

LEWIS JR., W. M., 1983, A revised classification of lakes based on mixing. Can. Journ. Fish. Aquat. Sci., 40: 17791787.
NIEMER, E., 1989, Climatologia do Brasil. 2a ed. Instituto Brasileiro de Geografia e Estatística, Rio de Janeiro, $307 \mathrm{p}$.

OLRIK, K., 1994, Phytoplankton ecology: determinating factors for the distribution of phytoplankton in freshwater and the sea. Danish Environmental Protection Agency, Denmark, 183p.

PAYNE, A. I., 1986, The ecology of tropical lakes and rivers. John Wiley \& Sons, New York, 310p.

PEARL, H. W., TUCKER, W. \& BLAND, P. T., 1983, Carotenoid enhancement and its role in maintaining bluegreen algal (Microcystis aeruginosa) surface blooms. Limnol. Oceanogr., 28(5): 847-857.

POOLE, H. H. \& ATKINS, W. R. G., 1929, Photo-electric measurement of submarine ilumination through out the year. Journ. Mar. Biol. Assoc., 16: 297-324.

REYNOLDS, C. S., 1984, The ecology of freshwater phytoplankton. Cambridge University Press, Cambridge, $384 \mathrm{p}$.

REYNOLDS, C. S., 1989, Physical determinants of phytoplankton succession. In: U. Sommer (ed.), Plankton Ecology. Succession in plankton communities. SpringerVerlag, Berlin, pp. 9-56.

REYNOLDS, C. S., 1992, The role of fluid motion in the dynamics of phytoplankton in lakes and rivers. In: P. S. Giller, A. G. Hildrew \& D. G. Raffaelli (eds.), Aquatic ecology scale, patterns and process. Blackwell Scientific Publications, London, pp. 141-187.

REYNOLDS, C. S., 1994, Are phytoplankton dynamics in rivers so different from those in shallow lakes? Hydrobiologia, 290: 1-21.

REYNOLDS, C. S. \& WALSBY, A. E., 1975, Water blooms. Biol. Rev., 50: 437-481.

SAWYER, C. N. \& McCARTHY, P. L. M., 1978, Chemistry for environmental engineering. $3^{\text {rd }} \mathrm{ed}$. McGraw-Hill Book Company, New York, 352p.

SHEAR, J. \& WALSBY, A. E., 1975, An investigation into the possible light-shielding role of gas vacuoles in a planktonic blue-green algae. Brit. Phycol. J., 10: 241 251.

STRUFFALDI-DE-VUONO, Y., 1985, Fitossociologia do estrato arbóreo da floresta da Reserva Biológica do Instituto de Botânica (São Paulo, SP). Ph.D. Thesis, Universidade de São Paulo, Brasil, 213p.

TETT, P., 1990, The photic zone. In: P. J. Herring, A. K. Campbell, M. Whitfield \& L. Maddock (eds.), Light and life in the sea. Cambridge University Press, Cambridge, pp. 59-87.

VINER, A. B. \& SMITH, I. R., 1973, Geographical, historical and physical aspects of Lake George. Proc. R. Soc. Lond.: ser. B, 184: 235-270.

WETZEL, R. G., 1993, Limnologia. Fundação Calouste Gulbenkian, Lisboa, 905p. (Translation to Portuguese and preface by Maria José Boavida.) 